\title{
O bom filho a casa torna \\ Gobineau refugiado na hierarquia familiar
}

Helga Gahyva

O diplomata, jornalista e escultor Arthur de Gobineau (1816-1882) conquistou notoriedade em função, sobretudo, de seu Essai sur l'inégalité des races humanes ${ }^{1}$, publicado entre os anos de 1853 e 1855. Segundo certa e hegemônica perspectiva, esse tratado sobre raças teria conferido a seu autor o destacado papel de pai do racismo moderno (Cassirer, 1997). Entretanto, o estudo detido da obra, especialmente em diálogo com a tradição germanista elaborada durante a querela das duas raças ${ }^{2}$ - e da qual, cremos, é Gobineau herdeiro - revela-nos um conceito de raça ainda bastante próximo de sua versão pré-revolucionária e, portanto, insuficientemente afinado com seu entendimento moderno. Em outros termos, se ele chegou a esboçar elementos de uma concepção de "raça-espécie", não se libertou da noção de "raça-linhagem" (cf. Remi-Giraud, 2003, pp. 203-221).

Ao conceito de linhagem subjazem três noções que hoje se apresentam de modo relativamente autônomo: classe social, nação e raça. A reflexão gobiniana, entretanto, concebia a nobreza, cujas características morais se transmitiam geracionalmente, como uma nação à parte - ela possuía linhagem (cf. Gahyva, 2012). Nesse sentido, defendemos a hipótese segundo a qual a concepção racial de Gobineau permaneceu marcada por uma concepção de linhagem própria de meados do século XVIII, na qual localizamos as primeiras formulações que versam sobre um princípio de incomunicabilidade entre as gentes, o qual se transmite geracionalmente.

1. Doravante denominado apenas Essai.

2. Embate político entre defensores e opositores da centralização monárquica - romanistas e germanistas, respectivamente -, no qual estes últimos recorrem às supostas origens superiores da nobreza francesa para denunciar a ilegitimidade das pretensões niveladoras do poder real. 
Trata-se da perspectiva própria à ideologia germanista desenvolvida durante a querela das duas raças.

A polêmica fora inaugurada pelo conde Henri de Boulainvilliers, doravante porta-voz da posição germanista. Em Histoire de l'ancien gouvernement de la France - obra que circulou clandestinamente em fins do reinado de Luís XIV, mas só foi publicada em 1727 -, o nobre litigante retomava os antigos debates quanto às origens dos franceses para reivindicar a manutenção de privilégios que, por direito, seriam exclusivos à nobreza francesa. Apenas os membros desta compartilhariam a origem ariana que lhes tornariam descendente dos conquistadores francos e, por derivação, assegurava-lhes uma série de prerrogativas reiteradamente usurpadas durante a formação da monarquia absoluta.

Não cabe ao escopo deste artigo detalhar a narrativa de Boulainvilliers, tampouco refazer a trajetória da querela. Interessa-nos, para fins de sustentação de nosso argumento, perceber que, ao atribuir somente à parte do povo francês uma origem franca, a reação germanista denunciava a divisão fundamental embutida na pretensa ideia de nacionalidade. À nobreza querelante, porque descendente dos antigos guerreiros arianos, estaria reservado o exercício das funções públicas; ao restante da população, formado pela mistura de raças inferiores (romanos, gauleses etc.) deveria vedar-se o acesso ao governo da nação. Nesse movimento, o partido germanista clamava às "leis fundamentais do reino" para cindir a nacionalidade e justificar as prerrogativas de uma nação transterritorial com códigos específicos: a nobreza (cf. Foucault, 2002, p. 169). Subjacente a essa concepção, a convicção segundo a qual um título nobiliárquico pressupunha um conjunto de disposições societárias inacessíveis às meras determinações da pena real, pois as características da nobreza se reproduziam geracionalmente e envolviam, portanto, o pertencimento a certa linhagem.

Ora, os tempos pós-revolucionários, sabemos, caracterizam-se pela desqualificação dos privilégios ancestrais coletivos em face da valorização da igualdade legal entre os indivíduos. Nessa chave, o pertencimento à linhagem torna-se valor de segunda ordem, dado que os vínculos familiares deixam de ser pré-definidores dos lugares sociais. Trata-se de uma nova configuração histórica na qual se anacronizam as hierarquias sociais próprias às sociedades de ordens. Gobineau constrói sua crítica à sociedade moderna a partir da constatação da falência desses outrora critérios distintivos: se não há mais barreiras estamentais entre os homens, a mistura torna-se a regra geral. Residia aí simultaneamente seu profundo pessimismo quanto 
ao futuro da moderna civilização e suas desesperadas e inglórias tentativas de buscar novas formas de distinguir os seres humanos em uma sociedade crescentemente democrática.

Apreciação semelhante pode ser encontrada em "La vie et le prophéties du comte de Gobineau", série de conferências que, em 1904, Robert Dreyfus proferiu na École des Hautes Études en Sciences Sociales. Segundo esse autor, o empenho intelectual de Gobineau tem como meta última estabelecer os fundamentos científicos e filosóficos característicos a uma moral aristocrática. Por trás desse esforço, Dreyfus identifica sua inadequação existencial àquele mundo igualitário profetizado por Aléxis de Tocqueville nas páginas de $A$ democracia na América. Se, para este último, a igualdade era um fato providencial irresistível e irreversível (cf. Tocqueville, 1998, p. 11), Gobineau concentrava suas energias na intenção de estabelecer algum critério hierárquico adaptado aos novos tempos.

Nesse sentido, o presente artigo inspira-se nas sugestões de Dreyfus com o objetivo de revelar como, a partir de três obras de Gobineau, podemos acompanhar os esforços deste último para estabelecer novas distinçôes entre os homens. Ou, em outras palavras, como ele pretendeu inserir formas de desigualdade em um mundo crescentemente igualitário. Utilizaremos, além do Essai, o romance Les pléiades, publicado em 1874, e Histoire de Ottar $\mathrm{Jar}^{3}$, suas supostas memórias genealógicas, editadas em 1879. Em cada um desses livros, Gobineau esboça um princípio hierárquico: no primeiro, a hierarquia racial; em Les pléiades, a hierarquia individual; no último, enfim, a hierarquia familiar.

Cumpre notar que a dimensão cronológica é deveras importante: a passagem de um critério distintivo a outro responde às insuficiências internas que Gobineau acaba por identificar em cada um deles. Por outro lado, a transição de uma forma a outra não implica ruptura. Se tomarmos o exemplo da substituição da hierarquia racial para a individual, perceberemos que se trata, antes, do recrudescimento de uma preocupação que lhe atormentava pelo menos desde o período de redação do tratado sobre as raças. Em depoimento a Tocqueville, datado de 1854 - portanto, da época em que se empenhava na redação do segundo tomo do Essai-, ele adiantava aqueles incômodos que o levariam, nos anos de 1870, a buscar uma distinção individual. Referindo-se Gobineau a "algumas centenas de espíritos que se mantêm vivos, apesar da atonia geral” (Tocqueville, 1959, p. 221), ele parecia já sugerir que, não obstante o processo degenerativo ao qual se submetia a moderna civilização, determinados espíritos nobres conseguiam
3. Doravante denominado apenas Ottar Jarl. 
4. No Velho Mundo, as civilizaçōes indiana, egípcia, assíria, grega, chinesa, romana e germânica; na América, as três grandes civilizaçôes pré-colombianas. transcender o vulgo, resguardando uma heterogeneidade inexoravelmente comprometida na era da unidade (Gobineau, 1983a, p. 1163). Por fim, a necessidade de alteração nos fundamentos hierárquicos guia-se sempre pelo mesmo motivo: a ausência de indivíduos aptos a personificá-los. Decorre daí, inclusive, o fracasso de sua derradeira tentativa, tal como veremos adiante, ao analisarmos a hierarquia familiar esboçada em Ottar Jarl.

\section{A hierarquia racial}

Segundo Gobineau, os movimentos importantes da sociedade europeia tiveram sua origem na lenta penetração do elemento ariano nas camadas étnicas subjacentes. Assim como as demais grandes civilizações que povoaram o globo ${ }^{4}$, ela se tornou merecedora desse epíteto porque, em sua gênese, se encontrava a energia criadora singular à raça branca. Conforme mostramos em trabalho anterior, trata-se de energia sempre paradoxal, que civilizava porque misturava e, por isso mesmo, levava à degeneração (cf. Gahyva, 2012). Mas a ruína foi por vezes driblada pelo afluxo de novas migrações arianas aptas a resgatar a vitalidade outrora perdida.

Cumpria então indagar em quais confins do mundo estariam guardadas as reservas de sangue ariano que salvariam a Europa moderna da decadência. Gobineau passou em revista algumas das principais populações de seu tempo e destacou apenas três nas quais a ação dos germanos fazia-se ainda presente.

Em primeiro lugar, aquela terra da qual, cria ele, tinham partido seus antepassados: a Escandinávia, "o país dos próprios deuses, se o cristianismo o tivesse permitido" (Gobineau, 1983a, p. 1065). A maior parte das tribos arianas abandonou a península, mas era ainda lá que se encontrava com mais força a memória dos valores e das instituições germânicas. Infelizmente, atestava Gobineau, a região pecava por sua baixa densidade populacional, ou seja, o sangue ariano que corria nas veias norueguesas e suecas não tinha a força expansiva necessária para a regeneração da civilização europeia. Em função desse déficit numérico, "pode-se então afirmar que a última sede da influência germânica não está mais entre elas" (Idem, p. 1066).

Ao contrário do que fez crer a posteridade, não era na Alemanha que Gobineau reconhecia os herdeiros de sua raça de heróis, mas na Inglaterra. A mesma pena que no começo do Essai descartava a "doctrine des milieux" (Idem, p. 190), destacava agora as benesses trazidas pela localização geográfica da Inglaterra, cujo caráter insular fazia-lhe menos propícia às misturas étnicas do que as nações continentais. 
A nostalgia gobiniana exaltava a república igualitária dos arianos primitivos, porém ele tinha por certo que essa organização era sempre provisória. As raças superiores seriam guiadas por uma lei da atração ${ }^{5}$ que acabaria por levar esses iguais ao encontro de populações inferiores. Nesses casos inevitáveis, o princípio igualitário via-se comprometido. Temperado com seu apreço pela ordem, o instinto de liberdade ariano revelava-se, a longo termo, adequado a um regime monárquico hereditário, eletivo e regular, equilibrado pelo largo espaço concedido à liberdade individual. "Seu ideal é a monarquia delegada, constitucional, em uma palavra, à inglesa" (Seillière, 1903, p. 122).

Mas a anglofilia de Gobineau não se convertia em programa político, pois se as instituições inglesas guardavam ainda a lembrança dos antigos costumes, esquecê-los era apenas uma questão de tempo. A Inglaterra caminhava em direção à ruína, porém seus passos eram mais lentos do que alhures. $\mathrm{O}$ país já mostrava certos sintomas particulares a sociedades que caminhavam rumo à anarquia étnica.

A decadência inglesa teria sido incrementada em momentos definidores da história da Europa Ocidental: o fim das guerras religiosas, a revogação do Edito de Nantes, a Revolução Francesa - em todos esses momentos, a nação viu-se alterada pelo afluxo de elementos estranhos aos instintos arianos. Por fim, "o nascimento da grande indústria veio aumentar ainda mais este movimento, chamando sobre o solo nacional operários de todas as raças não germânicas" (Gobineau, 1983a, p. 1076). A alteração da constituição sanguínea da população introduzia a Inglaterra no rol das nações romanizadas. A miscigenação revelava suas dores e delícias. Por um lado,

A partir deste momento, a França foi mais bem compreendida por eles. Eles se tornaram mais literários no sentido artístico da palavra. Eles conheceram a atração pelos estudos clássicos; [...] eles tomaram gosto pelas estátuas, pelos quadros, pela música, e ainda que almas iniciadas há muito tempo, e dotadas, pelo hábito, de uma delicadeza mais exigente, as acusassem de carregar ainda uma sorte de rudeza e de barbárie, eles souberam recolher, neste tipo de trabalho, uma glória que seus antepassados não tinham conhecido nem invejado (Idem, pp. 1076-1077).

Por outro, "o sistema das leis inglesas perdeu sua solidez [...]. A aristocracia encontra seus adversários; a democracia, outrora desconhecida, proclama pretensões que não foram inventadas sob solo anglo-saxão” (Idem, p. 1077).

Gobineau se pergunta, então, se o espírito ariano teria sido conservado por aqueles insulares que cruzaram o oceano Atlântico. Ou seja, ele voltava
5. Para Gobineau (1983a, p. 167), apenas aquelas raças que conseguiam vencer a natural prevenção aos cruzamentos apresentavam predisposição ao desenvolvimento. Se todas as raças compartilhavam uma lei de repulsão que desautorizava o contato com o diferente - a miscigenação -, predominava naquelas superiores uma lei de atração que as induzia à mistura. 
seus olhares para os Estados Unidos com fins de averiguar se poderia sair do Novo Mundo a nova raça de heróis capaz de conter a ruína iminente.

Segundo ele, originalmente o continente americano compunha-se de elementos da raça amarela. Do Pacífico vieram os primeiros negros. Quando da chegada de navegadores islandeses arianos, iniciou-se a mistura que formou as três grandes civilizações pré-colombianas. A partir do século XVI, acelerou-se o movimento que dissolveu completamente a população branca, e cujos efeitos daninhos produziram, ao tempo de Gobineau, as repúblicas sul-americanas.

Ao norte do continente resistiam ainda populações com disposições morais caracteristicamente germânicas. Se o caráter da raça amarela correspondia, em muitos sentidos, à imagem do "homem médio" analisado por Tocqueville em seu estudo sobre a América (cf. Gahyva, 2012, pp. 156-157), diferente era o retrato que o Essai oferecia dos estadunidenses arianizados: "Suas magistraturas eletivas e temporárias, sua vigilância invejosa do chefe de Estado, seu gosto pelo fracionamento federativo, lembram muito as vicampatis dos hindus primitivos" (Gobineau, 1983a, p. 1136).

A mistura étnica que se processou nos Estados Unidos fez emergir um tipo singular de democracia. Contrariando a tendência europeia e, mais especificamente, francesa, a igualdade nessa porção do Novo Mundo revelava-se compatível com o respeito às tradições, ilustrado sobremaneira na preferência pelo direito consuetudinário. Desconhecia-se aquele instinto revolucionário que, algumas décadas depois, Gobineau atribuiu a seus patrícios. Em síntese, "no centro das emanações modernas que os envolvem, um sabor de obsoleto que, para nós, está aliado a lembranças feudais" (Idem, p. 1137), e que podia ser exemplificado pelo inconfessável valor que os norte-americanos conferiam às distinções sociais.

Entretanto, se Gobineau inicialmente louvava as virtudes germânicas da população local, logo em seguida ele assegurava a inevitabilidade de seu declínio. Ora, como garantir a estabilidade de uma população permanentemente revirada por fluxos migratórios compostos pelos detritos das sociedades europeias? Segundo seu diagnóstico fatalista, assim como na Escandinávia e na Inglaterra, nos Estados Unidos a potência ariana não tardaria a perecer:

Quanto à renovação da sociedade humana, quanto à criação de uma civilização superior ou ao menos diferente, o que, no juízo das massas interessadas, dá sempre no mesmo, eis que são fenômenos que só são produzidos pela presença de uma raça relativamente pura e jovem. Esta condição não existe na América. Todo o trabalho 
deste país se limita a exagerar certos lados da cultura europeia, e nem sempre os mais belos, a copiar o melhor que podem o resto, a ignorar mais de uma coisa. Este povo, que se diz jovem, é o velho povo da Europa, menos contido pelas leis mais complacentes, e não mais bem inspirado. [...] A simples transferência de um ponto a outro não regenera as raças demasiadamente desgastadas (Idem, p. 1142).

Pela primeira vez na história da humanidade, portanto, o sangue ariano revelava-se estéril. Maculados por sucessivas alianças, quantitativamente inferiores à multidão mestiça que os rodeavam, aos poucos descendentes da nobre raça restava apenas a contemplação privilegiada da decadência. Nenhuma missão regeneradora era-lhes facultada. A tendência era a absorção lenta desses derradeiros elementos no seio das massas modernas.

Segundo ele, a fusão racial conduziu as civilizações precedentes à anarquia étnica. A solução despótica fora a alternativa própria para que se governassem os agregados heterogêneos. Em momentos diversos, a decadência estancou-se devido à entrada em cena de populações privilegiadas. Contemporaneamente, comprometeu-se o vigor ariano. Daí a particularidade dos novos tempos: desta feita, a heterogeneidade chegava a seu termo. As combinações étnicas agora irrefreáveis e unívocas unificaram aquilo que, nas sociedades precedentes, permaneceu múltiplo, e a moderna civilização europeia transformou-se em um todo homogêneo. A era da unidade era a versão gobiniana para o fim da história.

[...] o último termo da mediocridade em todos os gêneros: mediocridade de força física, mediocridade de beleza; mediocridade de aptidões intelectuais, podendo-se quase dizer “vazio”. Esta triste herança, cada um possuirá uma porção igual; motivo algum existe para que um tal homem tenha um lote mais rico que um tal outro; [...] todos os homens se parecem. [...] Eles terão a mesma dose de forças físicas, direções idênticas em seus instintos, medidas análogas em suas faculdades, e este nível geral, mais uma vez, será a mais revoltante humildade (Idem, p. 1164).

Em outras palavras, a vitalidade e a pluralidade singulares à organização hierárquica cederam seu espaço à ordem democrática. A propriedade comum, ou melhor, sua distribuição equitativa, era o previsível ponto de chegada de uma civilização que transformou a terra em um bem material. Arruinada a feudalidade, ela se divorciava dos laços familiares que outrora lhe forneciam sentido. A linhagem era o elemento que garantia a pluralidade da civilização ocidental. Seu enfraquecimento, a longo prazo, conduzia à 
igualdade universal. Sob o léxico racial, "o horror da igualdade pregada pelos demagogos de todas as idades, eis a razão de ser do Essai sur l'inégalité des races" (Seillière, 1903, p. 12).

Categoria moderna, a raça pertence paradoxalmente ao passado - o Essai, ao fim e ao cabo, versa sobre a inutilidade presente da ideia de raça. Melhor dizendo: à medida que a ordem estamental se comprometia em seus fundamentos, esboçava-se um novo tipo de distinção. A raça é gêmea do dogma igualitário. Mas, para Gobineau, a igualdade se realiza na mistura entre as raças. A déblâcle do mundo hierárquico era sintoma daqueles momentos nos quais as civilizaçôes atingem tamanho padrão de contato racial que não é mais possível decompô-la em seus elementos iniciais. A se considerar as lições do Essai, a descoberta da importância do fator racial na ascensão e na queda das civilizações não ultrapassa uma dimensão contemplativa, pois ela é, afinal, simultânea à constatação da impossibilidade de restaurar a "pureza racial" perdida.

Em síntese, o intuito de Gobineau em estabelecer uma distinção baseada em fundamentos raciais soçobrou em seu próprio imobilismo: se o regenerador sangue ariano esgotou-se em um passado distante, que sentido haveria em estabelecer um princípio de distinção irrealizável no presente? Para escapar da encruzilhada, Gobineau sacrificou sua concepção de nobreza de raça em prol de uma mais abrangente - e talvez realizável - noção de nobreza espiritual. Trata-se da passagem de uma hierarquia racial para uma hierarquia individual.

\section{A hierarquia individual}

$\mathrm{Na}$ contramão do crescente processo de especialização das ciências, típico da segunda metade do século XIX (cf. Lepenies, 1996), Gobineau abria mão do vocabulário pretensamente científico e escolhia as páginas de um romance para esboçar sua hierarquia individual. Por trás do esforço em dar vida a Les pléiades, a convicção segundo a qual "não há mais classes, não há mais povos, mas somente, em toda a Europa, algumas individualidades a flutuar como destroços sobre um dilúvio" (Gobineau apud Gaulmier, 1983b, p. 934). Percebamos que a citação não inclui "não há raças", afinal se não havia classes nem povos (nações?), não havia, igualmente, raças. $\mathrm{O}$ mundo moderno careceria daquele substrato que em eras pré-revolucionárias contemplava essas três noções: a linhagem - "não há famílias de fils de roi" (Gobineau apud Gaulmier, 1983b, p. 939). 
Em qual sentido Les pléiades representava o esforço de seu autor em estabelecer uma hierarquia fundada em critérios individuais? Qual seria o estatuto dessas individualidades? Residiria nelas alguma missão histórica? Haveria Gobineau encontrado a chave para a regeneração da civilização que ele cria destruir-se sob seus olhos?

O romance inicia-se com a reunião ocasional de três homens, que pouco se conhecem, em um jantar às margens do Lago Maggiori, em Isolda Bela, no norte italiano. Nesse primeiro momento, Wilfried Nore, inglês nascido em Bagdá, Conrad Lanze, jovem escultor alemão, e Louis de Laudon, típico francês do Segundo Império ${ }^{6}$, travam conversas nas quais discorrem sobre suas histórias pessoais. Eles se reencontram algum tempo depois no principado alemão de Burbach, cenário da maior parte dos eventos. Paris, "a enorme caravana de ociosidade, cobiça e farra de toda a Europa" (Gobineau apud Gaulmier, 1983c, p. 1063), é reduzida a um lugar de passagem. A Inglaterra evocada por Nore é aquela outrora habitada por cavaleiros normandos. "Sou unicamente um produto dos livros" (Gobineau, 1983b, p. 26), gaba-se o personagem. Uma alma de elite é inimiga do século e, por derivação, de seus mais destacados produtos: o espírito cultivado é incompatível com a vida nos grandes centros urbanos.

Gobineau expressou sua hierarquia individual nos dois primeiros capítulos do livro. Antes de cada personagem descrever suas experiências pregressas, o autor explicita qual elo uniria três homens praticamente desconhecidos entre si. A identificação surge quando trocam impressões sobre a mediocridade dos novos tempos. O que os fazia escapar da degeneração? A resposta foi fornecida pelo inglês: "Somos três calenders, fils de roi" (Idem, p. 14).

Laudon questiona a afirmação do inglês, alegando faltar-lhe a aparência de um ser de elite. Nore responde-lhe sem hesitação: "Vós examinais a questão de um lado único e, precisamente, o mais insignificante" (Idem, p. 14). Instaura-se a polêmica: o inglês põe em xeque a dimensão da ancestralidade, insistindo no tema da aprendizagem. Um fils de roi, segundo Nore, não se define por critérios meramente fenotípicos. Não se trata de atavismo, pois "não é questão de majestade desconhecida à qual a personagem tenciona dever a nascença", mas de "qualidades particulares, preciosas, em virtude das quais se eleva naturalmente, a despeito do vulgar" (Idem, p. 15, grifos nossos). Para reforçar o argumento de Nore, reproduzimos a citação na qual ele explica a Laudon o que significa se proclamar um fils de roi:
6. Isso nunca é dito por Gobineau, mas é consensual entre parte expressiva de seus comentadores (cf. Morland, 1905). 
Isso significa: "Sou de um temperamento ousado e generoso, alheio às sugestôes ordinárias dos naturais comuns. Meus gostos não são os da moda; eu sinto por mim mesmo e não amo nem odeio devido à indicação do jornal. [...] Enfim, por uma consequência muito lógica de tais premissas, não me contento com aquilo que satisfaz a plebe e procuro entre as gemas que o céu outorga aquilo que se reserva aos homens afeitos a joias que não aquelas com que a plebe se deleita” (Idem, pp. 15-16).

O alemão, por sua vez, reconhece uma contradição na fala de Nore: se são atributos que elevam o homem naturalmente, eles devem estar, de alguma forma, ligados à linhagem da qual descendem; são, talvez, qualidades que se transmitem por meio do sangue. Afinal, como desenvolver tais características em um ambiente cada vez mais hostil ao surgimento de espíritos nobres?

A emergência dessas individualidades pujantes merecedoras do epíteto de plêiade era, à primeira vista, independente de qualquer contexto histórico. $\mathrm{O}$ processo de aprendizagem pelo qual passavam os grandes espíritos iniciava-se pela negação do tempo presente. Não à toa, a trama do romance praticamente prescindia de substrato histórico - foram poucas as referências ao período no qual se desenrola a narrativa de Les pléiades. Na verdade, importava a Gobineau definir a moral particular dos cada vez mais raros seres de elite que formavam sua plêiade, tal como revelava Lanze:

[...] não me interesso pela massa disso que chamam de homens. Suponho que, dentro do plano da criação, tais criaturas tenham uma utilidade, posto que já a vi: elas nos incomodam e nós as repelimos. [...] O mundo moral é em todos os aspectos semelhante a esse céu estrelado onde se encontram nesse momento as magníficas profundezas. Meu olhar não o descobre, não o busca, não o deseja mais que para ver esses seres cintilantes que, com a cabeça coroada de esplendor eterno, agrupam-se inteligentemente nos espaços infinitos, atraídos, associados pela lei de uma misteriosa e irrecusável afinidade. [...] e me parece bastante natural e justa essa ideia, sempre presente, em todos os séculos, sob todas as formas de sociedades, sob todas as condiçôes de existência e com todas as leis religiosas, pairando no pensamento dessa gente honesta, essa gente de consciência e pujança, esses homens que sabem pensar e executar, e que nunca deixaram, ao se isolarem da multidão, de se qualificarem como plêiade (Idem, p. 19).

Em oposição ao gênio romântico, o fils de roi gobiniano carecia de ímpeto transformador. Seu olhar para o passado não transcendia as fronteiras da con- 
templação, e sua única função imediata era explicar de forma relativamente coerente a débâcle inexorável da civilização ocidental. Se o gênio romântico é frequentemente entendido como síntese do espírito de sua época, o ser de elite que habitava as reflexões de Gobineau buscava negar seu próprio tempo: "tudo aquilo que a sociedade perde jamais desaparece, mas refugia-se nas existências individuais" (Idem, p. 236), alega o príncipe Jean-Théodore, outro personagem do romance. À semelhança de seu autor, suas criações refutavam o tempo presente. Se, como argumenta Jean Gaulmier, o livro é um típico bildungsroman (cf. Gaulmier, 1983b, p. 951), inexistem motivos para buscar conexões com o mundo exterior. $\mathrm{Na}$ era da unidade era mister preservar-se da mediocridade; a aprendizagem implicava refúgio.

Se é possível extrair uma leitura romântica da obra de Gobineau a partir da influência do germanismo alemão - tema que não será aqui privilegiado -, o estudo de Norbert Elias (2001) sobre a sociedade de corte permite uma associação entre o pensamento do escritor francês e um romantismo aristocrático composto como reação à formação da monarquia absoluta. Nessa chave, reforça-se o elo nostálgico entre os teóricos do feudalismo do século XVIII, partidários do germanismo, e Gobineau (cf. Gahyva, 2012).

Segundo Elias, o longo processo de curialização que transformou a nobreza de espada em nobreza de corte provocou uma experiência de "desenraizamento" que se configurou por meio da elaboração de uma imagem da vida provincial na qual "o passado assumia o caráter de uma visão onírica” (Idem, p. 220). À crescente exigência de autocontrole, característica da sociedade de corte, contrapunha-se o elogio à existência pastoral, alçada à condição de símbolo da inocência perdida.

Se esse romantismo aristocrático não deve ser confundido com sua posterior variação burguesa, pode-se extrair um padrão recorrente em ambas as experiências, dado pelas situaçōes estruturalmente semelhantes desses segmentos sociais. Certas camadas ${ }^{7}$ da nobreza de corte francesa a partir do reinado de Henrique IV e a burguesia alemã da virada do século XVIII para o XIX compartilharam uma orientação informada pela adaptação a mudanças estruturais em direção à crescente interdependência e diferenciação. A compreensão dessas mudanças, refletidas especialmente nas modalidades das coerções que os homens exercem uns sobre os outros, estava no cerne da idealização romântica daquelas formações sociais pretéritas. Os setores dominantes de uma nova formação estão submetidos a constrangimentos - coerções e autocoerções - mais potentes do que aqueles próprios às experiências pregressas.
7. O uso do termo camadas justifica-se à medida que "a ascensão de um novo tipo de determinada camada social - no caso, uma formação aristocrática - pode, como vimos, acompanhar a decadência de um tipo antigo da mesma camada, ou, em todo caso, de uma camada social para a qual se utiliza o mesmo conceito, sem que haja uma diferenciação clara e distinta entre o tipo ascendente e o tipo decadente da camada assim designada" (Idem, p. 223). 
8. Conforme assinalou Dreyfus (1905, pp. 21-22), “[...] ele preocupava-se sempre em permanecer fiel a si mesmo e à sua $[\ldots]$ hierarquia étnica e em combiná-la apenas com o código complementar de sua 'hierarquia individual', mas sem anular um pelo outro".
Assim, representantes dos estágios de desenvolvimento anteriores lhes parecem símbolos de uma vida mais livre. Tornam-se os representantes de ideais nostalgicamente admirados, os quais, no entanto, não são mais concretizáveis na vida social do presente ou do futuro. [...] Em outras palavras, faz parte dos traços essenciais das mentalidades e ideais românticos o fato de que seus representantes veem o presente como uma degradação à luz do passado, e o futuro - se chegam a ter em vista um futuro - apenas como uma restauração do passado idealizado, melhor e mais puro (Idem, p. 226).

O dilema dessa experiência romântica consistia em equilibrar as reivindicações de liberdade e a ordem social, pois os lamentos vinham de segmentos privilegiados. O risco era ser vítima de seu próprio sucesso. Gobineau parecia consciente do perigo: desvincular completamente raça e espírito poderia levar qualquer um a almejar pertencer ao seleto grupo dos fils de ro $i^{8}$.

Quando ainda escrevia o Essai, nos anos de 1850, ele apostava que sua explicação racial fundaria uma inédita forma de explicar os fenômenos sociais. Mais de duas décadas depois, seu ponto de partida tornou-se lugar comum. $\mathrm{O}$ universo intelectual próprio ao do último quartel do século XIX atribuiu estatuto de verdade à explicação racial: "em tal época, a ideia de raça não é mais somente objeto de especulações reservadas a uma elite erudita" (Moussa, 2003, p. 14). Daí que, seguindo o desejo de se divorciar do senso comum, cumpria a Gobineau problematizar, mesmo que de modo sutil, o conceito de "raça-espécie". O diplomata mantinha a crítica que fizera no Essai à noção de perfectibilidade (cf. Gobineau, 1983a, p. 252): se tornar-se um fils de roi requer aprendizado, este não é acessível a todos. Mas tampouco é exclusivo aos membros de determinada raça - inclusive porque contemporaneamente se teria comprometido o significado outrora conferido a esse vocábulo. Ao mesmo tempo que negava sua época e adiantava as conclusóes de Ottar Jarl, Gobineau libertava o conceito de fils de roi de sua roupagem exclusivamente racial, mas sem lhe atribuir autonomia em relação ao conceito de "raça-linhagem". Se a atitude distinta de Lanze deve "provir de qualquer coisa hereditária" (Gobineau, 1983b, p. 22), a utilização do pronome indefinido demanda reflexão. Notemos que o recurso à "raça-espécie", progressivamente distante de seus elos originários com a "raça-linhagem", fora por esse período incorporado ao discurso da burguesia liberal - ele já pertencia ao século. A miscigenação era unívoca na agenda liberal colonialista: o contato - ou melhor, o confronto (vitorioso) - era o agente do progresso. Se internamente a "raça-espécie" parecia 
manter proximidade com a noção de classe social (cf. Le Bon, 1910, p. 133), a independência entre os conceitos era bem mais ampla naquilo que se relacionava com seu uso no quadro da política colonialista. A raça não era mais, como em Gobineau, um argumento mobilizado por aqueles que pretendiam manter as distinções aristocráticas em reação à modernidade burguesa e, assim, tornava-se instrumento de promoção desta mesma modernidade. A expansão do Ocidente era para o diplomata, todavia, destacado sintoma da velocidade do processo degenerativo.

No mundo corrompido, ele dava voz àquele que, segundo os críticos, é o personagem mais identificado com o próprio autor: Casimir Bullet. No início de Les pléiades, Lanze é ainda moralmente próximo a seus patrícios contemporâneos. Seu aprendizado é orientado por Bullet, que já abandonara pátria, família, títulos, nomes e transformara-se em Candeuil: "Não conheço os costumes futuros para aprová-los, os hábitos futuros para admirá-los, as instituições futuras para respeitá-las e atrevo-me a dizer que aquilo que aprovo, aquilo que admiro, já se foi. Nada tenho a ver com o que acontecerá” (Gobineau, 1983b, p. 124).

Se aderisse plenamente à "raça-espécie", Gobineau se adequaria a seu próprio tempo. Em outras palavras, investir na abordagem raciológica particular às últimas décadas do século XIX implicaria abrir mão da qualidade de fils de roi - este necessariamente um derrotado. A nova hierarquia não poderia mais se sustentar na raça biologizada; se, no romance, ele tentou estabelecer uma hierarquia individual, o intento envolveu contradições. Se ele não chegou a estabelecer uma relação necessária entre o surgimento de uma alma de elite e suas características ancestrais, não afirmou a independência radical entre os termos. Nore termina seduzido pelas palavras de Lanze:

Aquilo que é uma espécie de combinação misteriosa e nativa; que é uma reunião completa em sua pessoa de elementos nobres - divinos, se assim o quiser -, que os antigos tinham plenamente e que as misturas trazidas pelas gerações subsequentes e suas alianças indignas vieram a disfarçar, velar, enfraquecer, atenuar, dissimular e fazer desaparecer; mas que, não estando mortos, de pronto reaparecem nos fils de roi a que nos referimos (Idem, p. 16).

Há de se notar, entretanto, que, a despeito das contundentes críticas de Gobineau a seu século, era-lhe impossível abdicar integralmente das verdades de sua época. Tanto no Essai, como em Les pléiades, ele ampliava sincrônica e diacronicamente seu diagnóstico e suas desconfianças em 
9. E também a Itália de Isola Bella.

10. Gaulmier (1983c, p. 988) destaca as semelhanças entre Gobineau e seus trois calenders: Lanze era escultor; Nore, por ter nascido em Bagdá, era familiarizado com o "Oriente". Lanze, por fim, tinha um histórico de saúde semelhante ao de seu criador - com quem também compartilhava a formação intelectual. Mas Gaulmier (Idem, p. 989) assinala que "são sobretudo Jean-Théodore e Candeuil que Gobineau toma por intérpretes de sua sensibilidade". Sabe-se que veio também de Dom Pedro II a inspiração para a composição do príncipe de Burbach Segundo Ludwig Schemann, primeiro biógrafo de Gobineau, o imperador brasileiro havia sido o modelo essencial para a criação do personagem (Idem, p. 985-986). relação à sociedade europeia. Seu intuito, afinal, era o de estabelecer uma lei universalmente válida, inscrita no terreno da natureza e não no da história. Gobineau assegurava, por exemplo, que o surgimento de um fils de roi era independente de uma configuração histórica pré-determinada; por outro lado, os tempos modernos eram, para ele, os menos propícios para o desenvolvimento dessas nobres figuras: quanto mais democratizada (ou miscigenada) uma sociedade, mais raros seriam aqueles capazes de romper com os valores e as práticas das massas. Poder-se-ia sugerir que, se não existia um ambiente especificamente propício à ascensão de uma alma de elite, haveria, ao contrário, certos ambientes que obliterariam seu aparecimento?

Eleger Burbach o principal cenário da trama de Les pléiades é bastante significativo, pois a Alemanha ${ }^{9}$ era então nação recentemente unificada. Podemos nos perguntar se foi o acaso que agrupou tantos fils de roi em um mesmo lugar, ou se uma organização política nos moldes de um principado seria mais propícia ao desenvolvimento dos atributos de seres excepcionais. O romance, sem dúvida, não oferece resposta clara à questão, mas pensamos poder respondê-la quando nos voltamos para o conjunto das reflexões de Gobineau. Como notou Sylvie André, reitera-se, em sua obra, a predileção por ambientes circunscritos: "sós [...] em uma atmosfera rarefeita e pura, os homens são reduzidos a si mesmos, longe das armadilhas do divertimento e da facilidade" (André, 1990, p. 14).

Esses lugares protegidos preservavam mais facilmente aqueles elementos que, para ele, soçobravam no turbilhão igualitário: hierarquia, descentralização e heterogeneidade. Se "a democracia é sem dúvida a forma de governo mais inconcebível para um pensador que vê na semelhança e na uniformidade categorias inimigas do Ser" (Idem, p. 32), Burbach significa, no caso de Les pléiades, uma ilha provisoriamente preservada no vasto e expansivo oceano democrático.

A hierarquia individual proposta em Les pléiades, contudo, conduziu seu autor a uma dupla encruzilhada. Se, por um lado, ele admitia a permanência de espíritos robustos em um mundo crescentemente medíocre, seus seres de elite não possuíam tarefas regeneradoras. Como afirma Lanze, sua missão no mundo era para consigo mesmo: "o fato é que eu desprezo soberanamente a política” (Gobineau, 1983b, p. 20). Não havia quaisquer garantias quanto ao futuro. A expectativa era a de que os fils de roi fossem cada vez menos comuns - ou mesmo extintos. O pessimismo de Gobineau adquiria vida por meio de Jean-Théodore ${ }^{10}$, que renuncia sua posição e recolhe-se em Palermo: "A crença no futuro de seu principado não lhe era mais possível. 
Sabia que, cedo ou tarde, quando fosse a ocasião, após um remanejamento europeu ou uma negociação que se faria inevitável, seus domínios iriam fundir-se ao território de uma grande monarquia vizinha. [...] Logo, não lhe caberia deixar filhos" (Idem, 1983b, p. 197). Ou seja, sua hierarquia individual via-se refém do mesmo obstáculo que fora instransponível no Essai: a ausência de representantes. Como estabelecer uma distinção sem sujeitos aptos a personificá-la?

Em segundo lugar, como notou Dreyfus (1905, p. 31), o foco nas qualidades individuais levava Gobineau a um tipo de "aristocracia ao acaso". Se a um simplório dervixe não estava vedado o caminho que poderia (e)levá-lo à condição de fils de roi, por que o mesmo não seria verdadeiro em relação à massa gaulesa? Pode-se sugerir, por outro lado, que o processo de aprendizagem estava condicionado a traços pré-existentes: Lanze se dobrou aos ensinamentos de Candeuil porque já era portador das virtudes distintivas características de um fils de roi. Mas quais seriam essas virtudes? Deriva provavelmente da resposta a tal indagação a dificuldade de Gobineau em abdicar completamente do tema da linhagem. Uma alma de elite envolve atividade de espírito, paciência obstinada e paixão pela independência. As três características podem ser agrupadas sob um mesmo conceito: honra.

Lucien Febvre identifica duas variações possíveis ao sentimento de honra. Há uma honra exterior que se manifesta como marca de consideração externa aos homens. Trata-se, segundo o autor, de uma distinção de classe: "honneur oblige" (Febvre, 1998, p. 60). Seu principal exemplo é Montesquieu, para quem a honra corresponde ao "preconceito de cada pessoa e de cada condição" (Montesquieu, 2000, p. 36). Já a honra interior, personificada nos heróis cornelianos, representa um sentimento que conduz a renúncias e sacrifícios; ela implica uma recusa a compactuar com aquilo que se julga vulgar.

$O$ viés interior da honra envolve relações com uma determinada coletividade. Trata-se de sentimento que tende a se "enfraquecer na medida em que os grupos detentores de um código de honra particular sofrem os golpes das grandes transformaçóes que abalam nossas sociedades quase que em seus fundamentos" (Febvre, 1998, p. 67), mas, mesmo travestida modernamente como uma razão de agir individual, suas soluçôes são sempre coletivas. A honra, sob quaisquer variaçōes, constitui imperativo herdado que tem por raiz o elogio ao exemplo fornecido pelos fundadores. Por isso, ela indica pertencimento a uma categoria privilegiada.

Entretanto, a paixão pela independência que caracteriza os honrados personagens de Gobineau passa ao largo do desejo de mudança; ela significa, 
11. Após sua aposentadoria, em 1876, Gobineau não mais teve domicílio fixo. antes, um refúgio nostálgico. Quando rompe com sua época, uma alma de elite não o faz em função de um ímpeto transformador. $\mathrm{O}$ isolamento constitui tentativa de preservar em seu ínfimo microcosmo aqueles valores varridos em sua época. Se os preceitos da honra constituem uma espécie de depósito das distinções pregressas, os fils de roi são os fiadores desse patrimônio imaterial.

A honra própria aos personagens de Les pléiades poderia ser interpretada como uma daquelas razões de agir individuais, características do mundo moderno, mas ela mantém elementos do sentimento de pertencimento à linhagem. Gobineau, entusiasta do mundo feudal, recuava ainda mais no tempo, atribuindo aos seus fils de roi uma concepção desterritorializada de honra: tal como o diplomata no crepúsculo de sua existência ${ }^{11}$, eles circulam por várias paragens, mas não se apegam diretamente ao solo que ocupam. Eles não formam nem uma classe, nem uma nação; podem até não se encontrar no curso de uma vida, mas compartilham um inominável que se impõe naturalmente.

\section{A hierarquia familiar}

A centralidade do conceito de honra na reflexão de Gobineau explicita-se quando observamos as diferenças entre Les pléiades e Ottar Jarl. Em face daquele duplo obstáculo, Gobineau procura estabelecer uma combinação entre as hierarquias racial e individual. Entregando-se definitivamente à resignação, ele sintetiza em sua fantasia genealógica a derradeira tentativa de fundar uma distinção no mundo dos iguais: a hierarquia familiar.

Quis mostrar que a história dos homens, isto é, das famílias que são o homem completo, seria uma base mais real de conhecimentos do que as coleçôes de generalidades que se costuma dar como explicação da história e que mudam a cada dez anos com o espírito das populações mestiças que as imaginam, e pensei inventar assim uma novidade útil a propor" (Gobineau apud Raeders, 1938, pp. 312-313).

Nem a generalidade de um fundamento racial que, na perspectiva da "raça-espécie", além de hodiernamente inócuo, agrupava sob uma mesma coletividade elementos moralmente díspares; nem o individualismo atomista ao qual poderiam conduzir as reflexóes esboçadas em Les pléiades. Se o Essai dizia que o homem não existia senão como membro de sua raça e, naquele romance, ele só escapava à animalidade recolhido em seu pleno 
individualismo (cf. Gobineau, 1983b, pp. 18-19), a síntese viria em Ottar Jarl: o homem só adquire sentido na qualidade de membro da família.

Gobineau abandonou definitivamente seu tempo e aderiu a uma concepção racial cada vez mais assemelhada àquela desenvolvida pela nobreza litigante da querela das duas raças (cf. Gahyva, 2012). A chave para compreender a diferença entre os seres humanos residia na honra, um sentimento referencial e tônico "que não tem somente voz consultativa, nem mesmo voz deliberativa, mas voz imperativa" (Febvre, 1998, p. 78). Apenas por meio da linhagem perpetuavam-se os imperativos da honra - lignée oblige.

Entre o levantamento das fontes e sua redação, Ottar Jarl consumiu cerca de duas décadas. Mais uma vez, não se trata de uma mudança que possa ser caracterizada como uma ruptura, até porque é bastante curto o período entre a publicação dos dois livros - apenas cinco anos. O empenho de Gobineau em constituir um critério individual de diferenciação entre os homens esbarrou no tema da transmissão da honra. Se ele parece se libertar dos critérios fenotípicos - que, aliás, jamais foram decisivos -, permanece o problema da origem das qualidades morais. Ser membro de uma distinta linhagem não assegura o epíteto de fils de roi, mas a recíproca seria verdadeira? A se considerar as reflexões que ele expressa por meio dos personagens de seu romance, não se pode encerrar com precisão a questão, pois as páginas de Les pléiades não oferecem uma resposta unívoca.

Nesse sentido, pode-se compreender Ottar Jarl como a solução para uma indagação insuficientemente respondida naquele livro. Isso implica, em certa medida, considerar Les pléiades um ensaio em direção à conclusão da questão-chave de sua obra: como estabelecer um critério hierárquico próprio aos tempos pós-revolucionários?

Gobineau recorreu ao modelo das sagas escandinavas para contar a história da linhagem do pirata norueguês que empresta seu nome ao título. Segundo o autor, Jarl pertencia à linhagem dos Ynglingas, que remontava ao deus Odin. Os Gournay representavam o ramo de sua descendência que se fixou na Inglaterra e na Normandia. No século XV, eles passaram da qualidade de feudatários quase independentes à de vassalos ricos. Por meio de uma série contínua de filiaçôes e corruptelas linguísticas ${ }^{12}$, tornaram-se membros da burguesia de Bordeaux, atendendo agora pela alcunha de... Gobineau. Ou seja, o diplomata pretendia reconstituir a genealogia de sua própria família.

Dreyfus chama a atenção para os inconvenientes em considerar essas memórias sui generis como uma monografia sobre uma determinada linhagem. Em primeiro, por tratar-se de tarefa inglória: se Ottar Jarl
12. "[...] o nome comum aos últimos senhores de Gournay era, segundo Gobineau, Gauvin [...] e, pelos caprichos da fonética francesa, passou de Gauvin para Gauvenet, depois para Gobinet, e de Gobinet para Gobinot. De Gobinot para Gobineau" (Boissel, 1993, p. 25). 
13. Conferir, por exemplo, o testemunho do príncipe Philipp von d' Eulenburg, que se tornou bastante próximo de Gobineau a partir de sua temporada escandinava (cf. D'Eulenburg apud Dreyfus, s.d., p. 313). apresenta minuciosamente as fontes recolhidas na extensa pesquisa, peca pelas "muitas citações equivocadas, certas referências duvidosas e diversas escamotagens" (Dreyfus, 1905, p. 309). A bem da verdade, se ele dizia a Dom Pedro II que "a maior parte das pessoas na França não compreendem [sic] o que eu quis fazer" (Gobineau apud Raeders, 1938, p. 310), sequer os amigos mais chegados a Gobineau pareciam crer na veracidade de sua saga familiar ${ }^{13}$. A rigor, cabe perguntar-se em qual medida ele mesmo cria na autenticidade de sua narrativa.

A despeito dos lapsos internos, que comprometiam sua utilidade enquanto documento histórico, o livro desperta interesse quando analisado na perspectiva de uma história da honra. Como revelou Dreyfus, "a trama dessa história [...] não é outra coisa senão um estudo sobre os conflitos entre a honra verdadeira e as obliteraçôes da honra” (1905, p. 317). O recurso à própria genealogia serviu como pano de fundo para Gobineau mostrar que, a despeito das transformaçóes históricas e sociais, o sentimento de honra perpetuava-se em certas linhagens.

As disposições morais dos primeiros descendentes do pirata norueguês correspondiam às características dos arianos descritos no Essai. A atividade de espírito, a paciência obstinada e a paixão pela independência que, em Les pléiades, compartilhavam os fils de roi estavam já presentes no tratado sobre as raças (Gobineau, 1983a, p. 996).

Para Gobineau, os arianos representavam a antítese das populaçôes galo-romanas porque animados por um elemento nelas ausente: a honra. Elaborado no seio do paganismo, esse sentimento impunha um modo particular de conceber a associação política bem como seu respectivo critério de concessão da soberania, que ia de encontro à ideia romana de pátria. A honra prescrevia um individualismo anárquico compatível com uma concepção de soberano assemelhada ao "rei de dupla conjuntura" que, no âmbito da querela das duas raças, louvara o conde Henri de Boulainvilliers (1727). Enquanto a pátria galo-romana venerava seu rei, a comuna independente ariana preferia um "síndico" (Gobineau apud Dreyfus, 1905, p. 327). Trata-se de uma tripla polaridade: de um lado ariano/honra/descentralização, de outro, galo-romano/pátria/centralização.

Pode-se dizer que a narrativa familiar de Ottar Jarl tinha como objetivo revelar as artimanhas da honra em sua desesperada tentativa de sobreviver à ascensão irreversível da pátria. $\mathrm{O}$ processo que deu origem ao moderno Estado-nação foi o mesmo que enfraqueceu o sentimento de honra - "quando os reis se tornaram todo-poderosos, a alma mudou” (Idem, p. 319). A 
partir do século XV, a antiga nobreza ariana foi paulatinamente substituída por uma "nova nobreza [que] nada possuía do gênio próprio às antigas famílias de origem germânica" (Idem, p. 322). A espontaneidade própria ao elemento ariano deu lugar ao estéril culto das aparências peculiar aos parvenus, que "não conhecem do brasão mais que as aparências decorativas, sem compreender o que somente às raças nobres ocorreria pôr em tal lugar [...]: a Honra" (Idem, pp. 316-317). A autonomia das municipalidades sucumbira à corte.

A despeito dessas transformações, a honra encontrou seus refúgios. No extenso período que vai do século XV à época de Gobineau, ela se reproduziu no seio de famílias de origem nobre que não aderiram à ficção fantasmagórica inventada pelos romanos, a pátria. Se a honra prescrevia um determinado modo de vida, era inútil procurá-la na corte; a verdadeira nobreza, aquela dos descendentes de Jarl - "últimos herdeiros da honra" (Idem, p. 326) pertencia à burguesia livre de Bordeaux.

O princípio hierárquico familiar já nascia temporalmente comprometido, pois Arthur de Gobineau era o derradeiro representante de sua linhagem; em sua autoatribuída qualidade de fils de roi, ele não deixava herdeiros. Ottar Jarl dava continuidade às conclusōes do Essai: em face da inédita impossibilidade de regeneração, concretizava-se a era da unidade. Por isso, a hierarquia era necessariamente provisória. Por meio de sua ficção familiar, Gobineau narrava a irreversível decadência da nobreza ariana.

Nesse movimento, ele restituía à raça seu significado original, aderindo plenamente à concepção de "raça-linhagem". A transmissão dos caracteres biológicos não garantia a superioridade da descendência. Aquela "raça-espécie" precariamente desenhada no tratado reencontrava seu elemento definidor: a família. "A Histoire de Ottar Jarlé de fato, dentro de sua concepção, a obra de um leitor de Montlosier e Boulainvilliers" (Seillière, 1903, p. 412). Quem sai aos seus não degenera. 


\section{Referências Bibliográficas}

ANDre, Sylvie. (1990), Gobineau: parcours mythiques d'une auvre. Paris, Lettres Modernes.

BOISSEL, Jean. (1993), Gobineau: biographie (mythes et réalité). Paris, Berg International.

BOulainVILliers, Henri de. (1727), Histoire de l'ancien gouvernement de la France: avec XIV lettres historiques sur les parlements où états généraux. Disponível em $<\mathrm{http}: / /$ visualiseur.bnf.fr/ark:/12148/bpt6k87689j>, consultado em 3/8/2010.

Cassirer, Ernst. (1997), El mito del Estado. Cidade de México, Fondo de Cultura Económica.

Dreyfus, Robert. (1905), La vie et les prophéties du comte de Gobineau. Paris, Calman-Lévy.

Elias, Norbert. (2001), A sociedade de corte: investigação sobre a sociologia da realeza $e$ da aristocracia de corte. Rio de Janeiro, Jorge Zahar.

Febvre, Lucien. (1998), Honra e pátria. Rio de Janeiro, Civilização Brasileira.

FouCAult, Michel. (2002), Em defesa da sociedade: curso no Collège de France (19751976). São Paulo, Martins Fontes.

GAHYVA, Helga. (2012), O inimigo do século: um estudo sobre Arthur de Gobineau (1816-1882). Rio de Janeiro, Mauad X.

Gaulmier, Jean. (1983a), "Introduction”. In: Gobineau, Arthur de. Euvres. Paris, Gallimard, vol. 3, pp. ix-lx.

(1983b), "Les pléiades: notice". In: Gobineau, Arthur de.. CEuvres.Paris, Gallimard, vol. 3, pp. 929-1009.

. (1983c), "Les pléiades: notes et variantes". In: GOBINEAU, Arthur de. Euvres. Paris, Gallimard, vol. 3, pp. 1018-1168.

Gobineau, Arthur de. (1983a), Essai sur l'inégalité des races humaines. In:

Euvres. Paris, Gallimard, vol. 1, pp. 133-1174.

(1983b), Les pléiades. In:

Euvres. Paris, Gallimard, vol. 3, pp. 3-302.

LE BON, Gustave. (1910), Leis psychologicas da evolução dos povos. Lisboa, Typografia de Francisco Luiz Gonçalves.

LePenies, Wolf. (1996), As três culturas. São Paulo, Edusp.

Montesquieu, Charles Secondant de. (2000), O espirito das leis. São Paulo, Martins Fontes.

Morland, Jacques. (1905), “Gobineau romancier: 'Les pléiades”. Mercure de France, Paris, 55 (189): 5-21, maio.

Moussa, Serga. (2003), “Introdution”. In: (dir.). L'idée de race dans les sciences humaines et la littérature (XVIIe et XIX siècles): Actes du Colloque International de Lyon (16-18 novenbre 2000). Paris, L'Harmattan, pp. 7-16. 
RAEDERS, George (org.). (1938), D. Pedro II e o conde de Gobineau: correspondências inéditas. São Paulo, Cia. Editora Nacional.

REMI-GIRAUd, Sylvianne. (2003), "Le mot race dans les dictionnaires français du XIX siècle". In: MOUSSA, Sarga (dir.). Lidée de race dans les sciences humaines et la littérature (XVIIe et XIX siècles): Actes du Colloque International de Lyon (16-18 novenbre 2000). Paris, L'Harmattan, pp. 203-221.

SEILliere, Ernest. (1903), Le comte de Gobineau et l'arianisme historique. Paris, Plon. TOCQueville, Alexis de. (1959), Euvres complètes: correspondance d'Alexis de Tocqueville et d'Arthur de Gobineau. Paris, Gallimard, vol. 9.

. (1998), A democracia na América: leis e costumes. São Paulo, Martins Fontes. (2000), A democracia na América: sentimentos e opiniōes. São Paulo, Martins Fontes.

\section{Resumo}

O bom filho a casa torna: Gobineau refugiado na hierarquia familiar

Extensa bibliografia confere a Arthur de Gobineau lugar central no desenvolvimento da filosofia racialista. Ele teria conquistado tal posição em função da repercussão do Essai sur linégalité des races humaines (1853-1855). Constatamos, porém, que se trata de obra muito comentada, mas pouco estudada. Uma investigação sobre suas bases revela-nos que ele não chega a elaborar um conceito de raça que se separe do de linhagem. Seu esforço para a construção de uma noção de "raça-espécie" esbarra em sua incapacidade de se libertar da "raça-linhagem". A hipótese ganha consistência quando analisamos o tratado sobre as raças em diálogo com suas obras posteriores. Em Les plêiades, publicada em 1872, ele problematiza sua perspectiva racial por meio da tentativa de construção de uma hierarquia individual. Contudo, tanto o viés racial quanto o individual soçobram no seu pessimismo fatalista. Em sua última obra, Histoire de Ottar Jarl, publicada em 1879, ele procura combinar essas hierarquias - racial e individual. O livro é uma fantasia genealógica na qual ele se põe em linha direta de descendência com o deus Odin. Entregando-se à resignação, ele sintetiza na ficção de sua suposta ascendência a derradeira tentativa de fundar uma distinção no mundo moderno: a hierarquia familiar. Palavras-chave: Hierarquia; Igualdade; Honra; Século XIX. 


\section{Abstract}

The good child comes back home: Gobineau taking refuge in family hierarchy

An extensive bibliography assigns Arthur de Gobineau with a central role in the development of racialist philosophy. This position arose largely from the repercussion of his Essai sur l'inégalité des races humaines (1853-1855). It is notable, though, that the work is much commented on, but little studied. An investigation of its background reveals that he does not elaborate a concept of race that different from that of lineage. His effort to construct a notion of 'race-species' collides with his apparent inability to escape from the 'race-lineage' model. This hypothesis is further substantiated when we compare his treatise on races with later works. In Les plêiades, published in 1872, he problematizes his racial perspective through the attempt to construct an individual hierarchy. However both the racial and individual approaches become dissipated in his fatalist pessimism. In his last work, Histoire de Ottar Jarl, published in 1879, he looks to combine these hierarchies - racial and individual. The book is a genealogical fantasy in which he places himself in a direct line of descent from the god Odin. With a tone of resignation, the fiction of his supposed origin summarizes his final attempt to found a distinction within the modern world: family hierarchy.

Keywords: Hierarchy; Equality; Honour; Nineteenth Century.

Texto recebido em 30/8/2010 e aprovado em 24/1/2013.

Helga Gahyva é professora adjunta do Departamento de Sociologia do IFCS/UFRJ. E-mail: <gahyva@superig.com.br>. 